\title{
Revelations of character
}

Characters appear to change during the course of the play as in Coriolanus' case because of circumstances - or because we are given more information and see in new ways. Characters are either unstable or unlikeable. Aufidius is perhaps too much of a function to be regarded as evidence but there is the obvious case of Menenius. At first we are told that he is 'honest' and 'one that has always loved the people'. But the people do not seem to realise that his speech to them about the state as a body and his blaming the drought on the gods is patrician ideology and propaganda. Part of his effectiveness is the bubbling, old honesty he pretends. He tells the tribunes 'what I think, I utter, and spend my malice in my breath' [II.i.55]. Later, however, whatever he says is likely to be a lie or premeditated for political effect. He is like the tribunes, Aufidius and Volumnia, in trying to use Coriolanus for his own ends. Like many moderate figures he is made a bit absurd by Shakespeare. He is convinced that the world consists of people like himself who are governed by simple comforts and desires, and that all he needs do is to appeal to Coriolanus after the latter has eaten and is 'dieted to my request'. It is difficult not to see either Menenius' predatory nature or Shakespeare's ironic attitude towards him in the language 'then I'll set upon him' [v.i.58]. Before the Volsces, he speaks of Coriolanus in such a way that detracts from the warrior's achievement and makes us wonder if Menenius always lies. He claims he has always amplified and 'varnished' Coriolanus. He appears absurd when he asks 'has he dined?' Where is the spontaneous, honest tongue he claimed? The speech to Coriolanus is such an awkward clumsy artificial mess that it seems likely Shakespeare has the knife into Menenius and is making certain that we judge him. It will be noticed that most of the characters except Coriolanus are made less attractive after Act III.

\section{Coriolanus and his mother}

At the core of each of Shakespeare's plays is some fundamental 